Forfatterne makter i stor grad å gjøre stoffet forståelig for en kliniker. Dette til tross for at nevrobiologien er meget komplisert. En dypere innsikt i det molekylære «samliv» vil ofte begrenses til de spesielt interesserte.

I noen av de første kapitlene kan omtalen av laboratoriefunn og sammenhengen mellom disse oppleves som noe tung. Heldigvis har de fleste temaene en god avsluttende konklusjon, som for mange lesere vil fungere som en bekreftelse på graden av forståelse av de forutgående sidene.

En perle hva angår innhold og didaktisk fremleggelse er kapitlet til Inturrisi \& Gregus om mekanismene ved opioid toleranse. Dette er et vanskelig emne som har ledet til stor forskningsaktivitet verden over, og som står sentralt i forståelsen av virkemåten for den mest benyttede medikamentgruppen innen behandling av kreftsmerter.

Siste del omhandler psykologiske aspekter ved kreftsmerter, innbefattet relevant klinisk forskning. Gjennomgangen av «mykere» temaer, f.eks. angst, katastrofetenkning og helsepersonells empati, var lærerik og vel anvendt tid. Spesielt likte jeg Morleys Attention Management. I det siste kapitlet tar forfatterne for seg problemene som pasient og behandler av kreftsmerter står overfor i utviklingsland.

Redaksjonen har gjort et godt arbeid med å sy sammen stoffet, som i utgangspunktet var separate forelesninger på en konferanse. Temaene er meget aktuelle, og man sitter igjen med inntrykket av å ha blitt tilført faglig ballast. Språket er godt, uten å være akademisk snirklete.

Boken kan, som det sies i forordet av en prominent britisk kollega, anbefales både forskere og klinikere som har interesse for kreftsmerter.

\section{Steinar Bjørgo}

Anestesiavdelingen

Akuttklinikken

Oslo universitetssykehus, Radiumhospitalet

\section{Lærebok i klinisk ledelse}

Tim Swanwick, Judy McKimm, red.

ABC of clinical leadership

78 s, tab, ill. Oxford: Wiley-Blackwell, 2010.

Pris GBP 20

ISBN 978-1-4051-9817-2

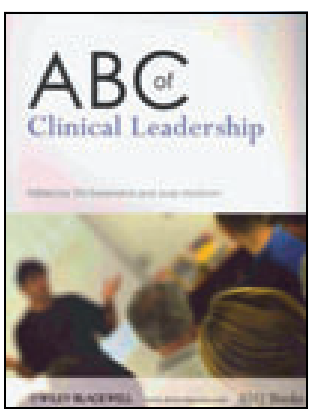

$A B C$ of clinical leadership er en interessant bok, dels fordi den utgis $i$ en medisinsk bokserie, men også fordi den gjenspeiler en ny tenkemåte innen ledelse og styring av helsetjenester.
Utgivelsen er forankret i britisk helsevirkelighet, hvor National Health Service (NHS) har vært en viktig premissleverandør for modeller for styring og finansiering av helsetjenester. Alvorlig kvalitetssvikt i helsetjenesten, bl.a. knyttet til hjertekirurgi på barn i 1990-årene, var en medvirkende årsak til at det ble reist krav om systemer for å sikre høy sikkerhet og kvalitet. Modeller og verktøy for overvåking og styring av klinisk virksomhet (clinical governance) ble implementert. Britiske helsemyndigheter har siden erkjent at det er vanskelig å oppnå god kvalitet gjennom ekstern styring alene, og oppmerksomheten er nå rettet mot klinikeren som leder. I 2008 lanserte NHS, i samarbeid med medisinske fagmiljøer, et rammeverk for hvilken kompetanse som kreves for å utøve klinisk lederskap. Dette er noe av bakgrunnsteppet for utgivelsen.

Målgruppen er leger og annet helsepersonell. De to redaktørene har med seg ytterligere 15 forfattere, som har bakgrunn som ledere, undervisere og leger. Boken er på 78 sider, består av 15 kapitler og er i A4format. Teksten er knapp, og det er lagt vekt på en pedagogisk fremstilling av stoffet, med utstrakt bruk av figurer, tekstbokser og illustrasjoner. Forfatterne forankrer teksten i sentral litteratur, men det sier seg selv at fremstillingen nødvendigvis vil bli overfladisk innen dette knappe formatet.

De første kapitlene om ledelse, administrasjon, endringsledelse og organisasjoner er gode, og likeså gir kapitlet om ledelsespsykologi et greit overblikk. En del av de andre kapitlene er litt for overfladiske, og eksempelvis omtaler forfatterne ledelse og kvalitetsforbedring på knappe fire sider. «Heroic leadership is dead!» fastslår forfatterne i kapitlet om ledelse og kjønn; et kapittel som etter min mening ikke gir leseren en balansert fremstilling. Det er for øvrig betegnende for kjønnsrollemønsteret i Storbritannia at ledelsesutfordringer knyttet til «career breaks» og «domestic commitments» er anført kun å gjelde kvinnelige ansatte.

Det er lett å peke på svakheter. Det kunne ha vært flere eksempler og referanser, færre gjentakelser (færre forfattere?), og teksten kunne ha være mer omfattende. Sett fra et norsk ståsted er det et minus at britisk lovverk ligger til grunn for enkelte kapitler. Tittelen og forordet signaliserer tydelig at boken er ment å være en enkel introduksjon, og jeg synes alt $i$ alt at redaktørene har lyktes rimelig bra. Boken er en grei start for medisinstudenter og leger som ønsker en elementær innføring i fagfeltet klinisk ledelse.

\section{Jan C. Frich}

Avdeling for helseledelse og helseøkonomi Institutt for helse og samfunn Universitetet i Oslo

\section{Tvilsom reklame for samfunnsmessig markedsføring}

Jeff French, Clive Blair-Stevens,

Dominic McVey et al, red.

Social marketing and public health

Theory and practice. 366 s, tab, ill. Oxford: Oxford University Press, 2010. Pris GBP 30 ISBN 978-0-19-955069-2

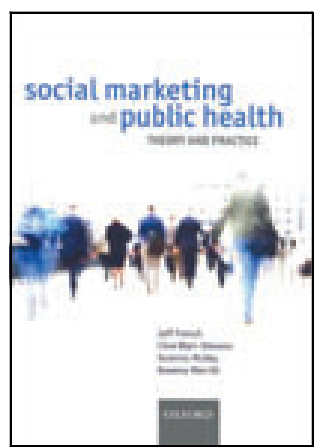

Uttrykket «social marketing» ble første gang brukt i 1971 og har senere vært definert på flere ulike måter. Denne boken bygger på følgende definisjon: «Social marketing is the systematic application of marketing alongside other concepts and techniques, to achieve specific behavioural goals, for a social good». Sentrale uttrykk er de fire p-er «product, price, place, promotion».

Boken har 21 kapitler og 19 forfattere, hvorav 17 er britiske og to er amerikanske. Kapitlene omfatter bl.a. utviklingen av samfunnsmessig markedsføring, atferdsteori, planlegging, gjennomføring og evaluering av tiltak. Kapitlene er klart disponert og begynner med «learning points» og «chapter overviews». Det er en rekke faktabokser, tabeller og figurer som skal lette innlæringen, og en omfattende bruk av kulepunkter.

Personlig fant jeg boken tunglest. Den er full av ord og uttrykk som blir svadapregede når de kommer i store doser: vision, holistic, powerful, design, insight, total process planning, framework, value for money etc. Tross alle fine ord er det ikke alltid like lett å se noe dypere innhold, og jeg tok meg stadig i å miste konsentrasjonen under lesningen. En del av kapitlene har et preg av å være konsulentrapporter for en betalende sponsor. Rent faktisk har også noen av forfatterne vært konsulenter for offentlige myndigheter. Enkelte kapitler var dog mer interessante, og man får en grei oversikt over teorier og modeller for atferdsendring.

En av ideene er at den som vil endre folks tanker, forestillinger og atferd, bør ta utgangspunkt i deres egne behov fremfor samfunnets behov. Dette er neppe kontroversielt, men boken gir ingen trylleoppskrift på hvordan man skal få det til. Snarere fremstår en del av forslagene som selvfølgeligheter. Når det gjelder dokumentert effekt av denne markedsføringen, sier forfatterne at «definite proof of effectiveness is often unobtainable». Denne boken kan være av interesse for helsearbeidere som driver med helseopplysning o.l., men klinikere 
som ønsker å hjelpe pasientene til atferdsendring, vil finne bedre og mer kortfattet innføring andre steder.

Ivar Sønbø Kristiansen

Institutt for helseledelse og helseøkonomi Universitetet i Oslo

\section{Enda mer kunnskap om det samme}

Adrianne E. Hardman, David J. Stensel Physical activity and health

The evidence explained. $340 \mathrm{~s}$, tab, ill.

Oxon: Routledge, 2009. Pris GBP 35

ISBN 978-0-415-42198-0

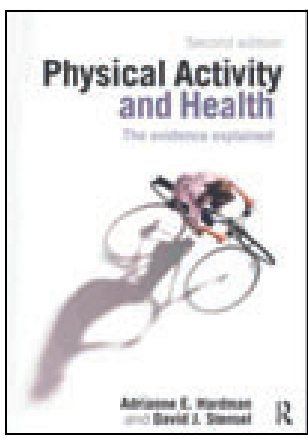

Fysisk aktivitet fremmer god helse og forebygger mange syk-

dommer, særlig vår tids store folkesykdommer. Trenger du å lese en hel bok med grundig vitenskapelig dokumentasjon for å godta denne

påstanden? Eller holder det med ovenstående setning?

Vi er kanskje forskjellig skrudd sammen. Noen av oss føler behov for å lese nok en bok for å være helt trygge på at det er helt sikkert at fysisk aktivitet er et nyttig hjelpemiddel - både for å forebygge og behandle de store folkesykdommene. For dem vil jeg anbefale Physical activity and health fordi den er lettlest og har søkelyset rettet mot tilstander der fysisk aktivitet virkelig gjør forskjell: diabetes, fedme, kardiovaskulære sykdommer, metabolsk syndrom, osteoporose, barn og aldring. Rygglidelser og psykisk sykdom glimrer forresten med sitt fravær. Du kan faktisk ikke være i tvil om nytten av fysisk aktivitet etter å ha lest deg gjennom disse kapitlene som buler av oppdaterte forskningsresultater - bare kildehenvisningene fyller 38 sider, altså over $10 \%$ av boken. Det man derimot kan undres på, er hva som er galt med forskningen som beviser det samme om igjen og om igjen, i stedet for å ta neste skritt: å lete etter praktisk bruk av det vi nå vet så altfor godt, og ikke trenger flere forskningsresultater på.

For oss som lever i en hverdag fylt av ørevoks og andre banaliteter, gir forfatterne en flott repetisjon i faget epidemiologi og hvordan man skal tolke forskningsresultater. Forfatterne gir også en god innføring i oppdatert viten om de ovennevnte sykdomsgruppene.

Spørsmålet er bare om vi skal bruke tid på å lese dette. Burde vi ikke snart komme oss et skritt videre og finne ut hvordan vi får befolkingen til å bedrive mer fysisk aktivitet - siden det er så helsebringende. Denne problemstillingen tar forfatterne ikke fatt i, og det har nok heller aldri vært intensjonen. Det er synd, for det er jo her det begynner å bli spennende.

Selv om boken er godt skrevet og har en lekker layout, vil jeg foreslå at potensielle lesere prioriterer tid, penger og leselyst på noe annet. Kom deg ut i marka og forebygg sykdom i egen kropp mens du grubler på hva som skal til for å sette forskningsresultatene ut i praksis!

\section{Jannike Reymert}

Bakklandet legekontor

Namsos

\section{Utmerket om idrettskardiologi}

Greg Whyte, Sanjay Sharma

Practical ECG for exercise science and sports medicine

167 s, tab, ill. Leeds: Human Kinetics, 2010 Pris GBP 22

ISBN 978-0-7360-8194-8

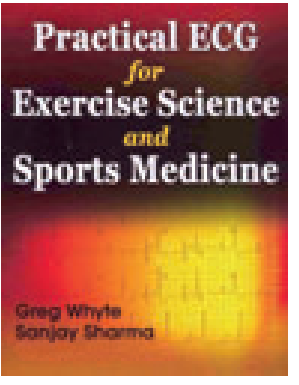

En sjelden gang skjer det sjokkerende: En idrettsutøver faller livløs om, iblant med «hele verden» som TV-tilskuer. De senere årene er man blitt mer oppmerksom på at selv om idrett er sunt

for de fleste, kan det være farlig for noen få. EKG hos toppidrettsutøvere kan ha bisarre forandringer. Hva er normal hjertefysiologi hos dem som trener mye? Hvordan skal en lege vurdere «patologiske» EKG-forandringer hos en tilsynelatende supersprek person? Hva med screening av utøvere en til dels opphetet debatt i mange land og med ulike løsninger? Bred interesse for mosjon, og ganske hard trening også blant eldre mosjonister, har dessuten gjort det viktig å differensiere normale og patologiske forandringer i hjertet som følge av intens trening.

Whyte og Sharma har skrevet en grundig, men lettlest bok om idretts-EKG. Begge forfatterne er internasjonalt meget kjente og har involvert seg i Cardiac Risk in the Young, en frivillig organisasjon som har nedlagt et stort arbeid for å redusere antall unge hjertedøde (1). Whyte er dessuten tidligere toppidrettsutøver. Sharma er sentral innen idrettskardiologi i European Society of Cardiology (2).

Boken er nærmest et kompendium, rikelig illustrert og tydelig med nøkkelpunkter. Den er basal og enkel, samtidig som den er avansert med komplekse problemstillinger. Boken er velegnet for flere som arbeider med fysisk trening og sport, men spesielt verdifull for indremedisinere, allmennleger og kardiologer. Særlig godt didaktisk er beskrivelsene av hjertets anatomi, elektrofysiologi og EKG-funn knyttet sammen.

I del 1 tar forfatterne for seg hjertets struktur, funksjon og anatomi, hjertets elektriske egenskaper, aksjonspotensialer, ledningssystemet, autonom regulering og kontraksjonsmønstre. De beskriver EKG i hvile og under aktivitet, og vanlige belastningsprotokoller.

Del 2 handler om normalt og unormalt hvile-EKG; rytme, intervaller, akser, morfologi, identifisering av forstørrede atrier og ventrikler, iskemi, brady- og takyarytmier, aksessoriske ledningsveier, kanalopatier, perimyokarditt, hypertrofisk kardiomyopati, elektrolyttforstyrrelser og medikamenteffekter. Forfatterne beskriver både normalfysiologiske og patologiske forandringer som kan opptre under trening, likeledes normalt og patologisk belastnings-EKG.

I del 3 beskriver forfatterne spesifikt idrettshjertet: Hva er fysiologiske forandringer? Hva er patologiske forandringer? Hjertets struktur og systoliske og diastoliske funksjon hos toppidrettsutøvere beskrives, med avgrensning av tillatt masseøkning, veggtykkelser og kammerdiameter hos begge kjønn. Kraftig økt vagustonus kan gi bradyarytmi, som hos utrente er patologi, men hos idrettsutøvere normalt. Synkope hos en idrettsutøver er alltid et varsel, og utredning er påkrevet. Forfatterne omtaler forekomsten av plutselig død i idrett og gjør det klart at de støtter idrettsscreening etter den europeiske modellen; enkel klinisk undersøkelse, egenanamnese og slektsanamnese og et 12-kanal-EKG

Boken avsluttes med seks svært interessante og lærerike kasuistikker.

\section{Erik Ekker Solberg}

Seksjon for hjertesykdommer

Diakonhjemmet Sykehus

\section{Anders Nesvold}

Hjertemedisinsk avdeling

Oslo universitetssykehus, Ullevål

\section{Litteratur}

1. Cardiac risk in the young. www.c-r-y.org.uk (11.3.2011)

2. Sports cardiology section. European Society of Cardiology www.sportscardiology.eu (11.3.2011). 